\title{
Gabriel Audisio, Une inquisition en Provence (Apt, 1532)
}

\section{Michele Mastroianni}

\section{Q OpenEdition}

1 Journals

\section{Edizione digitale}

URL: http://journals.openedition.org/studifrancesi/7863

DOI: 10.4000/studifrancesi.7863

ISSN: 2421-5856

\section{Editore}

Rosenberg \& Sellier

\section{Edizione cartacea}

Data di pubblicazione: 1 juillet 2009

Paginazione: 379

ISSN: 0039-2944

\section{Notizia bibliografica digitale}

Michele Mastroianni, «Gabriel Audisio, Une inquisition en Provence (Apt, 1532)», Studi Francesi [Online], 158 (LIII | II) | 2009, online dal 30 novembre 2015, consultato il 13 janvier 2021. URL: http:// journals.openedition.org/studifrancesi/7863 ; DOI: https://doi.org/10.4000/studifrancesi.7863

Questo documento è stato generato automaticamente il 13 janvier 2021.

\section{(c) (i) $\odot$}

Studi Francesi è distribuita con Licenza Creative Commons Attribuzione - Non commerciale - Non opere derivate 4.0 Internazionale. 


\title{
Gabriel Audisio, Une inquisition en Provence (Apt, 1532)
}

\author{
Michele Mastroianni
}

\section{NOTIZIA}

GABRIEL AUDISIO, Une inquisition en Provence (Apt, 1532), Paris, Champion, 2008 («Études et Essais sur la Renaissance», LXXXII), pp. 302.

G. Audisio fornisce la trascrizione del verbale del processo inquisitoriale cui fu sottoposto ad Apt, nel novembre 1532, il predicatore valdese Pierre Griot, trascrizione seguita da una traduzione-adattamento. Testimonianza interessante sul sinodo di Chanforan, che segnò l'adesione delle comunità valdesi alla riforma ginevrina, e sui metodi dei processi inquisitoriali, questa edizione interessa soprattutto gli storici della Riforma, cui è rivolta la puntuale ricostruzione documentaria. Offre nello stesso tempo un testo che interessa gli storici della lingua. 